\title{
Production and chemical composition of hydrophytes cultivated in aquaponics
}

\section{Producción y composición química de hidrófitas cultivadas en acuaponía}

\author{
Rosario Martínez-Yáñez ${ }^{1 *}$, Pedro J. Albertos-Alpuche ${ }^{1}$, Rafael Guzmán-Mendoza ${ }^{2}$, Lidia E. \\ Robaina-Robaina ${ }^{3}$, Alfonso Álvarez-González ${ }^{4}$, Daniel Díaz-Plascencia ${ }^{5}$ \\ ${ }^{1}$ Laboratorio de Acuicultura, Departamento de Veterinaria y Zootecnia, División de Ciencias de la Vida (DICIVA), Campus \\ Irapuato-Salamanca (CIS), Universidad de Guanajuato. Ex-Hacienda El Copal, km 7 carretera Irapuato-Silao, CP. 36821. \\ Irapuato, Guanajuato, México. \\ ${ }^{2}$ Departamento de Agronomía, División de Ciencias de la Vida (DICIVA), Campus Irapuato-Salamanca (CIS), Universidad de \\ Guanajuato. Ex-Hacienda El Copal, km 7 carretera Irapuato-Silao, CP. 36821. Irapuato, Guanajuato, México. \\ ${ }^{3}$ Departamento de Biología, Universidad de Las Palmas de Gran Canaria. Juan de Quesada, 30, 35001. Las Palmas de Gran \\ Canaria, España. \\ ${ }^{4}$ División Académica de Ciencias Biológicas de la Universidad Juárez Autónoma de Tabasco. Carretera Villahermosa - \\ Cárdenas, km 0.5 S/N, entronque a Bosques de Saloya, CP. 86150. Villahermosa, Tabasco, México. \\ ${ }^{5}$ Facultad de Zootecnia y Ecología de la Universidad Autónoma de Chihuahua. Peroférico Francisco R. Almada, km 1.0, CP. \\ 33820. Chihuahua, Chihuahua, México. \\ ${ }^{*}$ Corresponding author: ar.martinez@ugto.mx
}

Scientific article received: May 02, 2017 accepted: December 07, 2017

\begin{abstract}
Aquaponics can be defined as the integration of hydroponic plant production in a recirculating aquaculture system and has been proposed as a sustainable method to control the accumulation of waste produced by fish farming. The objective of the present study was to determine the biomass production and its feed potential of Myriophyllum aquaticum, Limnobium laevigatum, Lemna minor and Salvinia molesta grown in aquaponics. To evaluate the chemical compositions of these species, dry matter, organic matter, crude protein, neutral detergent fiber, acid detergent fiber, lignin, ash, ether extract, gross energy, calcium, and phosphorus of the aquatic plants were determined. Based on the results of this study, aquatic plants are considered to fulfill most of the nutritional requirements of productive animal species. Therefore, it is feasible to use them as the main ingredient in whole animal rations, with an emphasis on Myriophyllum aquaticum and Lemna minor as alternative food sources for different animal species, opening the way to aquaponic fodder production. Aquatic plants are interesting alternative, unconventional feed sources, especially because their high growth rates and nutritional qualities make it feasible to use them for animal consumption. However, Salvinia molesta has no value as fodder, especially because of its lignin concentration, which could affect the fodder digestibility.
\end{abstract}

Key words: Aquatic plants, biomass, fodder, nutritional characterization, Recirculation aquaculture systems (RAS)

RESUMEN. La acuaponía es una alternativa sustentable para el control de los desechos acumulados que se producen en los cultivos acuícolas, puede ser definida como la integración del cultivo de plantas en camas hidropónicas en un sistema de recircualción acuícola. El objetivo del presente estudio fue determinar la producción de biomasa y evaluar el potencial forrajero por medio de la composición química de Myriophyllum aquaticum, Limnobium laevigatum, Lemna minor y Salvinia molesta cultivadas en acuaponía. Se determino el contenido de materia seca, materia orgánica, proteína cruda, fibra neutro detergente, fibra ácido detergente, lignina, cenizas, extracto étereo, energía bruta, calcio y fósforo. Las plantas acuáticas evaluadas cubren los requerimientos nutricionales de la mayoría de las especies animales productivas, siendo posible su incorporación como ingredientes en las raciones para animales, en particular Myriophyllum aquaticum y Lemna minor son una alternativa para la alimentación animal, como forrajes acuapónicos. Las hidrófitas son una fuente no convencional y alternativa de forraje, por su rápido crecimiento y calidad nutrimental, para el consumo animal. Mientras que Salvinia molesta, no tiene valor como forraje por su concentración de lignina, 
lo que afecta su digestibilidad.

Palabras clave: Plantas acuáticas, biomasa, forrajes, caracterización nutrimental, sistemas de recilculacion acuicola (SRA)

\section{INTRODUCTION}

Aquatic plants are interesting alternatives to conventional food sources, especially because of their accelerated growth and nutritional quality (Leterme et al. 2009). Several studies have been conducted to determine the value of different nonconventional forage resources from the nutritional point of view, both for fish and for terrestrial animals (Patra et al. 2002). Considering distribution, hydrophytes are found almost everywhere (Lowe et al. 2000). Belonging to a group classified as weeds, several species have potential forage uses, especially parrotfeather (Myriophyllum aquaticum), which is widely used as ornaments in aquariums and presents considerably rapid growth (Crow 2007). Another aquatic plant is Amazon frogbit (Limnobium laevigatum), which is typified by accelerated growth and invasiveness and is considered a pest in many countries (San Martín and Boetscher 2003). Additionally, duckweed (Lemna minor) is a small aquatic plant that must be submerged to flower and is an almost cosmopolitan species; duckweed grows quickly and efficiently, as it is able to take advantage of residual waste for its growth (Reyes et al. 2011). Finally, aquatic fern (Salvinia molesta), which has been listed as an invasive plant due to its adaptability and fast reproduction, is able to grow at high speed blocking necessary sunlight from other aquatic plants, especially the algae necessary to oxygenate water (Lowe et al. 2000). Aquaculture waste can be used as a source of nutrients for plant growth in hydroponic systems, so it is possible to incorporate hydroponics into aquaculture. In this sense, aquaponics, defined as the integration of hydroponic plant production in a recirculating aquaculture system, has been proposed as a sustainable alternative to control the accumulation of waste produced by fish farming (Rakocy 2010). In general, aquaponics is a production system in which wastes synthesized by aquatic organisms (usually fish) are converted via bacterial action into nitrates, which serve as a source of nitrogen for plants. The principle of aquaponics is based on the fact that the nutrients required for the growth and development of plant cells are very similar to the wastes that fish produce and release into the water. The fish release nitrogen directly into the water via gill excretions in the form of ammonia $\left(\mathrm{NH}_{3}\right)$ (Forster and Goldstein 1969), which ionizes to form ammonium $\left(\mathrm{NH}_{4+}\right)$; subsequently, by the bacterial action of the genera Nitrosomonas and Nitrobacter, the ammonium transforms into nitrite $\left(\mathrm{NO}_{2-}\right)$ and nitrate $\left(\mathrm{NO}_{3^{-}}\right)$(Watson 1971). Plants are part of the biological filters of aquaponic systems and take the nutrients they need, such as nitrates, from the water, thus cleaning the water that returns to the fish tank (Espinosa et al. 2016) and allowing the fish to live in a suitable environment for its growth and development, while reducing the quantity of water that needs to be replaced. Thus, the objective of the present study was to determine the biomass production of the aquaponic species Myriophyllum aquaticum, Limnobium laevigatum, Lemna minor and Salvinia molesta and their potential for feeding animals.

\section{MATERIALS AND METHODS}

\section{Study area}

The present study was carried out in the Aquaculture Laboratory (LabAc-UG) of the Veterinary and Husbandry Department at the Life Sciences Division, Campus Irapuato-Salamanca of the University of Guanajuato $\left(20^{\circ} 44^{\prime} 34.42^{\prime \prime} \mathrm{N}\right.$ $101^{\circ} 19^{\prime} 50$." W; 1745 meters above sea level).

\section{Aquaponic experimental systems and fish}

A completely randomized design with three replicates per treatment was used (one species per aquaponics system, each system with three hydroponics beds, HB). Aquaponics systems were equal 
and independent, each consisting of a pond (1.5 $\left.\mathrm{m}^{3}\right)$, a clarifier $\left(0.25 \mathrm{~m}^{3}\right)$, a physical filter (formed by 2 containers, each $0.06 \mathrm{~m}^{3}$, with filtering material for the retention of particles), a biological filter (a plastic container of $0.25 \mathrm{~m}^{3}$ ) and $3 \mathrm{HB}$ (fiberglass container of $0.15 \mathrm{~m}^{3}$ with $1.0 \mathrm{~m}^{2}$ of sowing area, Vef $=0.1 \mathrm{~m}^{3}$ ) (Figure 1). Physicochemical parameters during the study were $\mathrm{pH}$ 7.8-8.2, dissolved oxygen (DO) $5-5.5 \mathrm{mg} / \mathrm{L}$, temperature $20-23{ }^{\circ} \mathrm{C}$, and electrical conductivity $1000-1280 \mathrm{mS}$ $\mathrm{cm}^{-3}$. The hydraulic retention time in the HB was 60 minutes, with a constant flow. PVC pipes were used for the water conduction lines, and the internal movement was carried out with a submersible pump (BOYU DJ4P-3000 ECO). The water flow was: pond $\rightarrow$ clarifier $\rightarrow$ physical filter $\rightarrow$ biological filter $\rightarrow \mathrm{HB} \rightarrow$ pond. In the pond, the air was injected (60 L min ${ }^{-1}$, BOYU ACQ-009 compressor) through a silicone hose $(\varnothing 4 \mathrm{~mm})$ connected to four diffusers. A total of 120 specimens of Oreochromis aureus were planted with an average weight of 6.7 $\mathrm{g}$ and a length of $7.2 \pm 0.8 \mathrm{~cm}$. The fish were fed to apparent satiation three times a day with a commercial feed (50\% protein and $15 \%$ fat).

\section{Hydrophytes}

The aquatic plants parrotfeather (Myriophyllum aquaticum), Amazon frogbit (Limnobium laevigatum), duckweed (Lemna minor) and aquatic fern (Salvinia molesta) were obtained from the aquatic plant collection of LabAc-UG. A total of $200 \mathrm{~g}$ of vegetable biomass on a wet basis were planted in each HB. The plants were allowed to drain for $30 \mathrm{~min}$ in a net in the shade to remove excess water before the amount required for each species was weighed. The experiment lasted for 21 $d$, and at the end of the experiment, the plants were removed from each $\mathrm{HB}$, the excess water was withdrawn and the biomass production per species was quantified $\left(\mathrm{g} \mathrm{m}^{-2}\right)$. Subsequently, the plant material was placed on a plastic tray (one tray per HB), and the biomass was divided into four portions per tray. Samples for the bromatological analysis were taken from each tray by sampling only one of the four portions ( $n=12$ per species, approx.
50-70 g). The samples were weighed and dried in an oven at $60{ }^{\circ} \mathrm{C}$ to constant weight to determine the dry matter (DM).

\section{Chemical analysis}

Three plant material subsamples per species were analyzed for organic matter (OM), crude protein (CP) (AOAC 2000), neutral detergent fiber (NDF) (method no. 6, Ankom 2014a), acid detergent fiber (ADF) (method no. 5, Ankom, 2014b), lignin (LIG) (method no. 8, Ankom 2005), ash (method 942.05, AOAC 1995), ether extract (EE) (Randall method, Thiex et al. 2003), gross energy (GE) (IKA Calorimeter System C 2000 Basic), calcium (Ca) (AOAC 2000) and phosphorus (P) (Edmond 1969) levels.

\section{Statistical analysis}

Biomass production data were analyzed by one-way ANOVA and Tukey's test. Square root transformation of the sine-arc was applied to the chemical composition data (percentage values) (McCune et al. 2002), due to the nature of these data, and they were analyzed by the Kruskal-Wallis test $(99 \%$ confidence) with the InfoStat computer program (Balzarini et al. 2008). Subsequently, matched comparisons were made between the means of the treatments to determine differences (Balzarini et al. 2008).

\section{RESULTS}

\section{Biomass production}

The biomass production of the aquatic plants grown in the aquaponics system are shown in Table 1. Significant statistical differences were observed in all variables evaluated among plant species $(\mathrm{p}<$ 0.05 ). According to our results, $L$. laevigatum produced the largest amount of fresh biomass matter, followed by $S$. molesta and L. minor; however, $M$. aquaticum presented the highest biomass yield of grams in dry matter $(106.36 \pm 2.23 \mathrm{~g}$ of dry matter), as well as the highest organic matter, crude protein, hemicellulose and cellulose contents in dry matter, in grams $(93.73 \pm 1.96,30.38 \pm$ 


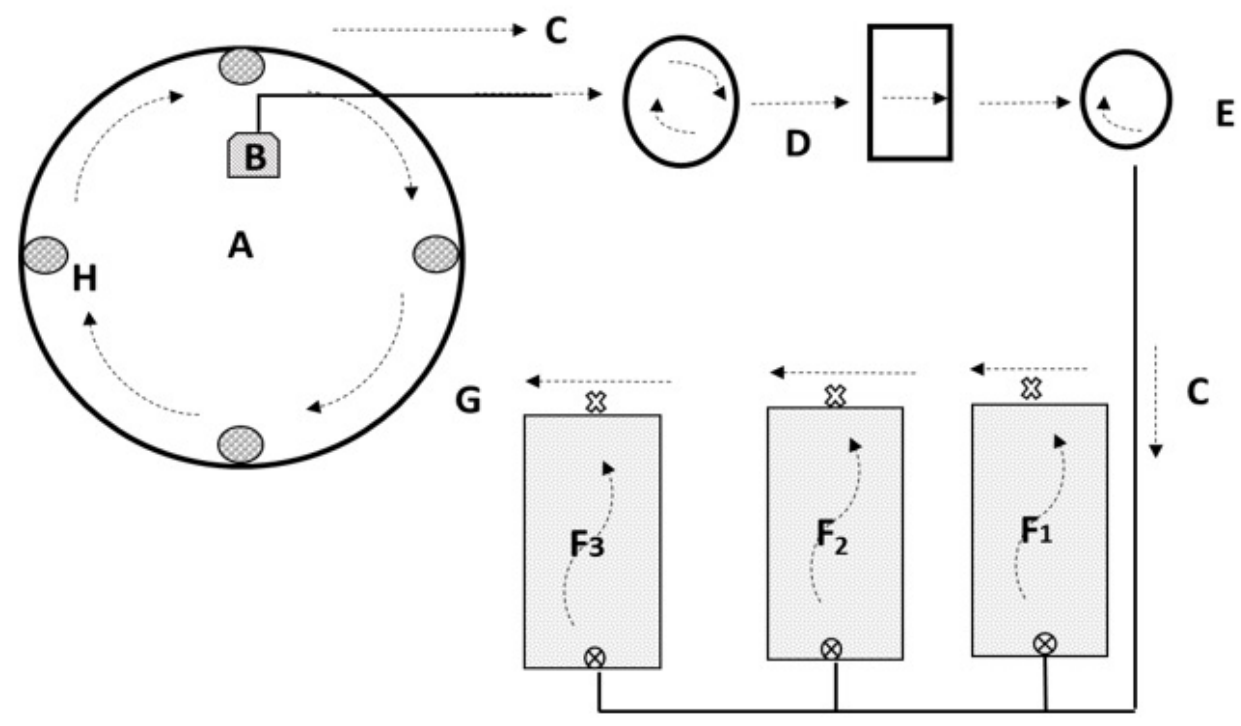

Figure 1. Aquaponic system design, where A) Pond, B) Water Pump, C) Water Circulation, D) Clarifier, E) Biological Filter, F) Hydroponic Beds, G) Water Outlet, H) Air Diffusers.

Table 1. Biomass production $\left(\mathrm{g} \mathrm{m}^{-2}\right)$ of hydrophytes cultured in the aquaponic system.

\begin{tabular}{|c|c|c|c|c|}
\hline & $\begin{array}{c}\text { Parrotfeather } \\
\text { Myriophyllum aquaticum }\end{array}$ & $\begin{array}{c}\text { Amazon Frogbit } \\
\text { Limnobium laevigatum }\end{array}$ & $\begin{array}{l}\text { Duckweed } \\
\text { Lemna minor }\end{array}$ & $\begin{array}{l}\text { Aquatic Fern } \\
\text { Salvinia molesta }\end{array}$ \\
\hline & \multicolumn{4}{|c|}{ Gram per $\mathrm{m}^{2}$ Fresh Matter } \\
\hline Wet Matter & $998.68 \pm 20.92^{c}$ & $1514.78 \pm 34.56^{a}$ & $1222.71 \pm 24.12^{b}$ & $1298.94 \pm 15.81^{a b}$ \\
\hline \multirow[t]{2}{*}{ Dry Matter } & $106.36 \pm 2.23^{a}$ & $69.83 \pm 1.59^{b}$ & $64.68 \pm 1.28^{b}$ & $61.05 \pm 0.74^{b}$ \\
\hline & \multicolumn{4}{|c|}{ Gram per $\mathrm{m}^{2}$ in Dry Matter } \\
\hline Organic Matter & $93.73 \pm 1.96^{a}$ & $57.08 \pm 1.30^{b}$ & $51.39 \pm 1.01^{b}$ & $49.81 \pm 0.61^{b}$ \\
\hline Crude Protein & $30.38 \pm 0.64^{a}$ & $20.22 \pm 0.46^{b}$ & $19.34 \pm 0.38^{b}$ & $13.26 \pm 0.16^{c}$ \\
\hline Hemicellulose & $20.48 \pm 0.43^{a}$ & $4.26 \pm 0.10^{d}$ & $6.80 \pm 0.13^{c}$ & $11.01 \pm 0.13^{b}$ \\
\hline Cellulose & $16.37 \pm 0.34^{a}$ & $12.81 \pm 0.29^{b}$ & $9.51 \pm 0.19^{c}$ & $6.06 \pm 0.07^{d}$ \\
\hline
\end{tabular}

$0.64,20.48 \pm 0.43$, and $16.37 \pm 0.34 \mathrm{~g}$, respectively).

\section{Chemical composition}

The chemical compositions of the aquatic plants grown in the aquaponic system are shown in Table 2. According to the bromatological analyses, $M$. aquaticum contained the highest amount of DM $(10.65 \pm 2.13 \%)$ and OM $(88.13 \pm 0.13 \%$ in DM). L. minor showed the highest CP values, followed by L. laevigatum and M. aquaticum (29.90 $\pm 1.08,28.96 \pm 0.35$ and $28.56 \pm 0.11 \%$ in the DM, respectively). The highest values of NDF were recorded in $S$. molesta and $M$. aquaticum (46.21 \pm 1.27 and $39.79 \pm 0.30 \%$ in the DM, respectively).
In addition, $S$. molesta had the highest value of FDA, followed by L. laevigatum ( $28.18 \pm 1.25$ and $26.88 \pm 1.42 \%$ in the DM, respectively). Regarding lignin concentrations, S. molesta had the highest value $(18.25 \pm 0.96 \%$ in DM), and the lowest lignin concentrations were observed in $M$. aquaticum and L. minor $(5.14 \pm 1.05$ and $5.28 \pm 0.38 \%$ in DM, respectively). The highest ash values were recorded in L. minor, followed by $S$. molesta $(20.55 \pm 0.50$ and $18.41 \pm 0.20 \%$ in DM, respectively). The highest values of EE and EB were observed in $M$. aquaticum $(4.25 \pm 0.35 \%$ in DM and $3.545 .5 \pm$ $8.22 \mathrm{cal} / \mathrm{g}$, respectively). The highest concentration of Ca was recorded in $L$. minor, followed by $S$. molesta $(0.26 \pm 0.02$ and $0.18 \pm 0.04 \%$ in $\mathrm{DM}$, 
Table 2. Chemical composition of hydrophytes grown in the aquaponic system.

\begin{tabular}{|c|c|c|c|c|}
\hline & $\begin{array}{c}\text { Parrotfeather } \\
\text { Myriophyllum aquaticum }\end{array}$ & $\begin{array}{c}\text { Amazon Frogbit } \\
\text { Limnobium laevigatum }\end{array}$ & $\begin{array}{c}\text { Duckweed } \\
\text { Lemna minor }\end{array}$ & $\begin{array}{c}\text { Aquatic Fern } \\
\text { Salvinia molesta }\end{array}$ \\
\hline & & $\%$ & & \\
\hline Dry Matter & $10.65 \pm 2.13^{c}$ & $\begin{array}{l}4.61 \pm 0.47^{a} \\
\% \text { in Dry Matter }\end{array}$ & $5.29 \pm 0.30^{b}$ & $4.70 \pm 0.47^{a}$ \\
\hline Organic Matter & $88.13 \pm 0.13^{c}$ & $81.74 \pm 0.15^{b}$ & $79.45 \pm 0.50^{a}$ & $81.59 \pm 0.20^{a b}$ \\
\hline Crude Protein & $28.56 \pm 0.11^{a b}$ & $28.96 \pm 0.35^{b c}$ & $29.90 \pm 1.08^{c}$ & $21.72 \pm 0.63^{a}$ \\
\hline Neutral Detergent Fiber (NDF) & $39.79 \pm 0.30^{b c}$ & $32.98 \pm 3.31^{a b}$ & $30.49 \pm 1.35^{a}$ & $46.21 \pm 1.27^{c}$ \\
\hline Acid Detergent Fiber (ADF) & $20.53 \pm 1.26^{a}$ & $26.88 \pm 1.42^{b}$ & $19.98 \pm 0.11^{a}$ & $28.18 \pm 1.25^{b}$ \\
\hline Hemicellulose** & 19.26 & 6.1 & 10.51 & 18.03 \\
\hline Cellulose** & 15.39 & 18.35 & 14.7 & 9.93 \\
\hline Lignin & $5.14 \pm 1.05^{a}$ & $8.53 \pm 1.09^{b}$ & $5.28 \pm 0.38^{a}$ & $18.25 \pm 0.96^{c}$ \\
\hline Ash & $11.88 \pm 0.13^{a}$ & $18.27 \pm 0.15^{a b}$ & $20.55 \pm 0.50^{c}$ & $18.41 \pm 0.20^{b c}$ \\
\hline Ether Extract & $4.25 \pm 0.35^{c}$ & $2.77 \pm 0.49^{b c}$ & $1.95 \pm 0.02^{a b}$ & $1.71 \pm 0.18^{a}$ \\
\hline $\mathrm{Ca}$ & $0.15 \pm 0.04^{a}$ & $0.14 \pm 0.03^{a}$ & $0.26 \pm 0.02^{b}$ & $0.18 \pm 0.04^{a b}$ \\
\hline $\mathrm{p}$ & $0.38 \pm 0.01^{a}$ & $\begin{array}{r}1.06 \pm 0.03^{c} \\
\mathrm{cal} / \mathrm{g}\end{array}$ & $0.96 \pm 0.01^{a b}$ & $1.01 \pm 0.02^{b c}$ \\
\hline Gross Energy* & $3545.5 \pm 8.22^{c}$ & $3123 \pm 38.34^{a}$ & $3218 \pm 12.60^{a b}$ & $3282.3 \pm 9.31^{b c}$ \\
\hline
\end{tabular}

respectively). L. laevigatum had the highest value of $p$, followed by $S$. molesta $(1.06 \pm 0.03$ and 1.01 $\pm 0.02 \%$ in the DM, respectively).

\section{DISCUSSION}

To the best of our knowledge, the present study is the first to show the biomass production and chemical composition of $M$. aquaticum, L. laevigatum, L. minor and S. molesta grown in aquaponics and their potential for feeding animals, which opens a wide range of new alternatives for feed. The hydrophytes evaluated in the present study contained amounts of DM as those studied by Reyes et al. (2011) and Aponte et al. (2013). The hydrophytes evaluated in the present study presented similar values of lignin as those reported in $M$. sativa (4\%, Varela et al. 2003), except for L. laevigatum and $S$. molesta (8.53 and $18.25 \%$, respectively). Lignin is a component of the cell wall, so higher concentrations of lignin in the forage decrease its digestibility and the availability of energy for animals, particularly those that obtain energy from the fermentation of fiber (Hussain and Durrani 2009). Therefore, it is feasible to use L. laevigatum in animal feed, but $S$. molesta could present problems in relation to digestibility and consumption.

Aponte et al. (2013) obtained L. laevigatum samples from wetlands and marshes and reported a value of $16.22 \%$ PC in DM. Subsequently, these specimens were grown in a controlled environment with hydroponic nutrient solutions, analyses showed values of $4.9 \% \mathrm{DM}$ and $2,500 \mathrm{cal} / \mathrm{g} \mathrm{GE}$, and, in dry basis, $95.1 \%$ OM, 26 to $30 \%$ PC, 1.18 to $2.55 \%$ fat, 7.63 to $8.0 \%$ crude fiber and 23.0 to $23.6 \%$ ash. According to our results, the $L$. laevigatum plants grown in the aquaponic system had similar values of DM, CP, and fat, higher GE values and lower ash values. Additionally, Corti and Schatteler (2002) reported that L. laevigatum under natural conditions can have as much as $16 \%$ protein in dry basis, which makes it an interesting potential forage plant; however, this concentration could change in the propagation processes under controlled conditions, where the light and space conditions are the most optimal and nutrients are not limiting, as is the case of aquaponics systems. According to Wersal and Madsen (2011), M. aquaticum has the capacity to absorb a significant amount of these elements in the water column because of its root system. Some authors who investigated Lemna sp reported a crude protein level of $29 \%$ in its DM (Ly et al. 2002), similar to the values obtained in this study. It should be noted that, in the present work, Lemna minor was the plant species with the highest amount of CP. Leterme et al. (2009) reported that Salvinia 
molesta contained 9.2 to $19.1 \% \mathrm{PC}$ in its DM, a lower value than those reported here. According to Jampeetong et al. (2012), aquatic plants are good candidates for removing $\mathrm{N}$ in aquaponic systems and had a high nitrate uptake rate when they were supplied with only this chemical compound. Nitrate is the form of nitrogen that plants absorb and use for growth. Plants assimilate most of the absorbed nitrate in organic nitrogen compounds; the nitrate is transformed into nitrite, which is transformed into ammonium, and the assimilated nitrogen is then incorporated into amino acids, which are used in protein synthesis (Sinha 2004), which translates into plant growth. It has been shown that the chemical composition of the nutrient solutions used in hydroponics modify the CP content in forages (Salas-Pérez et al. 2010). As part of an aquaculture recirculation system, the water in aquaponics always contains available ammonium and nitrate, which could explain the $\mathrm{CP}$ values observed in the hydrophytes of this study (range of 21.72 to $29.90 \%$ in DM) and those reported by Reyes et al. (2011), showing that the chemical composition of plants produced in aquaponic systems could be affected by the type of production system, which could be used to improve the plant nutritional quality. NDF values of $41.9 \%$ have been reported for Lemna minor (Ly et al., 2002), and NDF values of 51.8 to $62.9 \%$ have been reported for Salvinia molesta (Leterme et al., 2009), but the NDF percentages in the current study were lower. For ADF, the values obtained in the present study were slightly higher than the previously reported value of $15.6 \%$ for Lemna gibba (Landesman et al., 2010) and lower than the previously reported values of 35.8 to $41.4 \%$ for Salvinia molesta (Leterme et al., 2009). For ash, values of $23 \%$ in DM for L. laevigatum (Aponte et al. 2013) and $20.1 \%$ in DM for Salvinia molesta (Leterme et al., 2009) have been reported; our results were slightly lower than those reported by other authors. According to Leterme et al. (2009), Salvinia is a good source of minerals and essential amino acids; however, its use in pig feeding is limited due to its fiber content, which results in low digestible energy and protein. The nutritional requirements of productive species vary with the physiological state, age, and sex; however, it is essential that these requirements are met by considering the quality of the ingredients produced and used in diets. In this sense, crude protein $(\mathrm{CP})$ is the main nutrient in animal feed, since it fulfills various physiological functions in organisms (Elizondo-Salazar 2008). The $\mathrm{CP}$ requirement should be addressed in diets by considering the digestive capacity of the target species. The hydrophytes cultured in an aquaponic system evaluated in the present study met the crude protein percentages required to feed productive animals (Table 3), except for $S$. molesta, which did not meet the minimum protein requirement for tilapia diets. A fundamental component in the diet of herbivorous animals is the fiber present in forages. Excess fiber reduces the voluntary intake, digestibility, ruminal microbial protein synthesis, and energy intake of feed. For high-production animals that require significant energy inputs, fiber ranges must be established, because fiber is a factor that limits the energy content of rations. For the fiber component, NDF requirements vary. According to the results of our study, it is possible to feed these species with the evaluated hydrophytes. It is important to note that the content of DAF and lignin present in $L$. laevigatum and $S$. molesta that may limit their use as fodder, for example, increasing the content of ADF from $19-21 \%$ to $24-26 \%$ in the diet of rabbits increased mortality during fattening (Romero et al. 2009). Variable apparent digestibility values have been observed, ranging from 15 to $60 \%$ for hemicellulose, 5 to $25 \%$ for cellulose and -15 to $15 \%$ for lignin (Benkeblia 2014). On the other hand, the mineral contents in ingredients and diets are of vital importance in animal feed, since suitable concentrations of minerals are beneficial for production (Table 3). Considering our results, the ash contents of the hydrophytes meet the nutritional requirements to be incorporated in food for terrestrial species. Based on the $\mathrm{Ca} \mathrm{g} \mathrm{d}^{-1}$ requirements for dairy cows, pigs, poultry, sheep, goats, rabbits and tilapias, the hydrophytes do not provide enough $\mathrm{Ca}$ element, except for the tilapia, which, according to 
the literature, can survive with lower levels of $\mathrm{Ca}$ depending on the physico-chemical characteristics of the water (Llanes 2006). However, based on the results, the aquatic plants could meet some of the requirements for $P$. In relation to lipids (EE), the composition of the aquaponic hydrophytes meets the minimum requirements of most species, so the use of these hydrophytes as an ingredient in an integral ration is feasible. Finally, according to our results, the aquatic plants evaluated comply with the amount of energy needed (GE) for productive species.

\section{CONCLUSIONS}

Our results show that hydrophytes cultivated in aquaponics systems can fulfill most of the nutritional quality requirements for productive animal species, so it is feasible to use them as main ingredients in whole animal rations, especially Myriophyllum aquaticum and Lemna minor, as alternatives for feeding animals. This enables a type of non-conventional fodder production, although more research is needed, particularly regarding the consumption, attractiveness, palatability and digestibility of these hydrophytes grown in aquaponic systems for different animal species. Salvinia molesta, had no value as fodder, especially because of its concentration of lignin, which could affect the digestibility and voluntary consumption.

\section{ACKNOWLEDGEMENTS}

We thank the Directorate for Research and Postgraduate Support of the University of Guanajuato for the resources for the present investigation through project 960/2016. We also thank Dr. Antonio Lot Helgueras of the National Herbarium of the Institute of Biology, U.N.A.M., for the identification of the aquatic plant species in the present study.

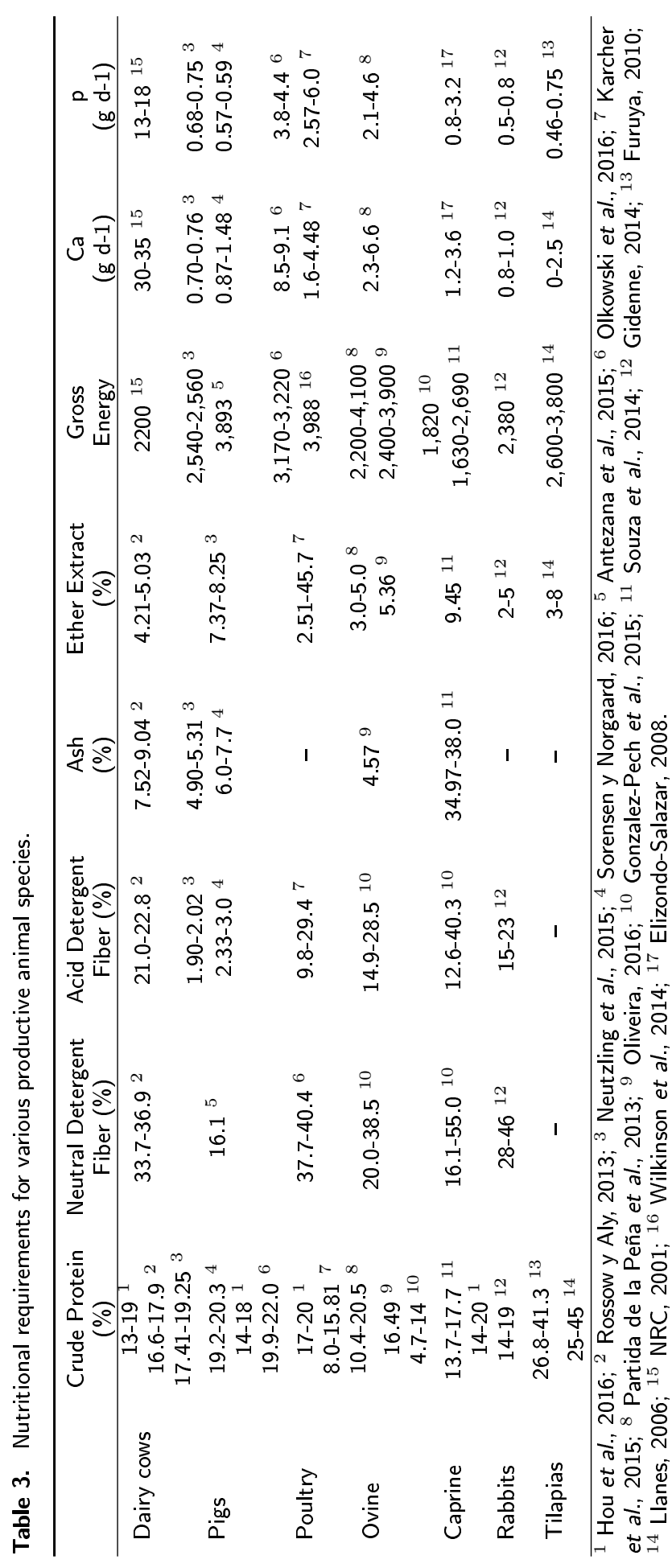




\section{LITERATURE CITED}

ANKOM (2005) Determining Acid Detergent Lignin in Beakers, ANKOM Technology Method 8. ANKOM Technology, Macedon, NY. https://www.ankom.com/sites/default/files/document-files/Method 8 Lignin_in_beakers_3_13_13.pdf. Date consulted: 21 october, 2016.

ANKOM (2014a) Neutral detergent fiber in feeds -Filter bag technique (for A200 and A200I), ANKOM Technology Method 6. ANKOM Technology, Macedon, NY. https://www.ankom.com/sites/default/files/document-files/Method_6_NDF_Method_A200_RevE_11_04_14.pdf. Date consulted: 21 october, 2016.

ANKOM (2014b) Acid detergent fiber in feeds -Filter bag technique (for A200 and A200I), ANKOM Technology Method 5. ANKOM Technology, Macedon, NY. https://www.ankom.com/sites/default/ files/document-files/Method_5_ADF_Method_A200_RevE_11_04_14.pdf Date consulted: 21 october, 2016.

Antezana W, Calvet S, Beccaccia A, Ferrer P, De Blas C, García-Rebollar P, et al. (2015) Effects of nutrition on digestión efficiency and gaseous emissions form sluring in growing pigs; III. Influence of varying the dietary level of calcium soap of palm fatty acids distillate with or without orange pulp supplementation. Animal Feed Science and Technology 209: 128-136.

AOAC (1995) Method 942.05. Association of Official Analytical. In: Cunniff P (ed) Official methods of analysis of AOAC International Association of Official Analytical Chemists. Washington, DC, USA. $1200 \mathrm{p}$.

AOAC (2000) Official methods of analysis of AOAC International. Horwitz W (ed). AOAC International Association of Official Analytical Chemists. Washington, DC, USA. 2200p.

Aponte H, Segura C, Francia JC (2013) Análisis químico proximal de Limnobium laevigatum y su potencial para su uso como forraje. Científica 10: 158-167.

Balzarini MG, Gonzalez L, Tablada M, Casanoves F, Di Rienzo JA, Robledo CW (2008) InfoStat, Manual del Usuario. Editorial Brujas. Córdoba, Argentina. 334p.

Benkeblia N (2014) Polysaccharides, Natural Fibers in Food and Nutrition. Editorial CRC Press. United Kingdom. 413p.

Corti P, Schlatter RP (2002) Feeding ecology of the Black-necked Swan Cygnus melancoryphus in two wetlands of southern Chile. Neotropical Fauna Environment 37: 9-14.

Crow GE (2007) Haloragaceae. In: Hammel BE, Grayum MH, Herrera C, Zamora N (ed). Manual de Plantas de Costa Rica. Volumen VI, Missouri Botanical Garden Press, USA. pp: 1-2.

Edmond CR (1969) Direct determination of fluoride in phosphate rock samples using specific ion electrode. Analytical Chemistry 41: 1327-1328.

Elizondo-Salazar JA (2008) Requerimientos nutricionales de cabras lecheras II. Proteína metabolizable. Agronomía Mesoamericana 19: 123-130.

Espinosa MEA, Angel SCA, Mendoza CJM, Albertos APJ, Alvarez-Gonzalez CA, Martínez-Yañez R (2016) Herbaceous plants as part of biological filter for aquaponics system. Aquaculture Research 47: 17161726.

Forster RP, Goldstein L (1969) Formation of excretory products. In: Hoar WS, Randall JC (ed) Fish Physiology. Volumen I. Academic Press, New York, USA. pp: 313-350. 
Furuya WM (2010) Tabelas Brasileiras para a nutrição de tilapias. Gráfica Editora, Toledo, Brasil. 100p.

Gidenne T (2014) Dietary fibres in the nutrition of the growing rabbit and recommendations to preserve digestive health: a review. Animal 9: 227-42.

González-Pech PG, Torres-Acosta JF, Sandoval-Castro CA, Tun-Garrido J (2015) Feeding behavior of sheep and goats in a deciduous tropical forest during the dry season: The same menú consumen differently. Small Ruminant Research 133: 128-134.

Hou Y, Bai Z, Lesschen JP, Staritsky IG, Sikirica N, Ma L, et al. (2016) Feed use and nitrogen excretion of livestock in EU-27. Agriculture, Ecosystems and Enviroment 218: 232-244.

Hussain F, Durrani MJ (2009) Nutritional evaluation of some forage plants from Harboi Rangeland, Kalat, Pakistan. Pakistan Journal of Botany 41: 1137-1154.

Jampeetong A, Brix H, Kantawanichkul S (2012) Effects of inorganic nitrogen forms on growth, morphology, nitrogen uptake capacity and nutrient allocation of four tropical aquatic macrophytes (Salvinia cucullata, Ipomoea aquatica, Cyperus involucratus and Vetiveria zizanioides). Aquatic Botany 97: 10-16.

Karcher DM, Jones DR, Abdo Z, Zhao Y, Shepherd TA, Xin H (2015) Impact of comercial housing systems and nutrient and energy intake on laying hen performance and egg quality parameters. Poultry Science 94: 485-501.

Landesman, L Fedler C, Duan R. (2010) Plant nutrient phytoremediation using duckweed. In: Ansari AA, Sarvajeet SG, Lanza GR, Rast W (ed) Eutrophication: Causes, consequences and control. Vol 1, pp: 341-354.

Leterme P, Londoño AM, Muñoz JE, Súarez J, Bedoya CA, Souffrant WB, et al. (2009) Nutritional value of aquatic ferns (Azolla filiculoides Lam. and Salvinia molesta Mitchell) in pigs. Animal Feed Science and Technology 149: 135-148.

Llanes J, Toledo J, Fernández I, Lazo de la Vega JM (2006) Nutrición y alimentación de tilapias. Revista de la Asociación Cubana de Producción Animal 4: 51-54.

Lowe S, Browne M, Boudjelas S, De Poorter M (2000) 100 de las especies exóticas invasoras más dañinas del mundo. Global Invasive Species Database. http://www.iucngisd.org/gisd/pdf/100Spanish.pdf. Date consulted: 10 february, 2017.

Ly J, Samkol P, Preston TR (2002) Nutritional evaluation of aquatic plants for pigs: pepsin/pancreatin digestibility of six plant species. Livestock Research for Rural Development 14(1). http://www. Irrd.cipav. org.co/Irrd14/1/ly141a.htm. Date consulted: 23 March 2018.

McCune B, Grace JB, Urban DL (2002) Analysis of ecological communities. Gleneden Beach, Oregon, USA. $294 p$.

NRC (2001) Nutrient Requirements of Dairy Cattle. National Research Council. National Academy Press. Washington, D.C., USA. 408p.

Neutzling FB, Lovatto PA, Nogara RP, de Oliveira V, Rigon RC, Lehnen CR (2015) Modeling performance and nutritional requirements of pigs lots during growth and finishing. Ciência Rural Santa Maria 45: 1841-1847.

Nie HT, Zhang H, You JH, Wang F (2015) Determination of energy and protein requirement for maintenance and growth and evaluation for the effects of gender upon nutrient requirement in Dorper $\times \mathrm{Hu}$ Crossbred Lambs. Tropical Animal Helth and Production 47: 841-53. 
Oliveira CD, Souza AK, Dos Santos R, Veloso da Mata VJ, Sampaio OL, Gomes DI, Mezzomo R (2016) Body composition and energy and protein nutritional requirements for weight gain in Santa Ines crossbred sheep. Tropical Animal Health and Production 48: 683-688.

Olkowski B, Charuta A, Radzki R, Bienko M, Toczko R (2016) Skeletal response to diet with soya vean sedes used as primary source of protein in growing broiler chickens. Journal of Animal Physiology and Animal Nutrition 100: 731-737.

Partida de la Peña JA, Braña VD, Jiménez SH, Ríos RF, Buendía RG (2013) Producción de carne ovina, Centro Nacional de Investigación Disciplinaria en Fisiología y Mejoramiento Animal. Ajuchitlan, Querétaro. Libro Técnico No. 5. 116p.

Patra BC, Maity J, Debnath J, Patra S (2002) Making aquatic weeds useful II: Nymphoides cristatum (Roxb.) O. Kuntze as feed for an Indian major carp Labeo rohita (Hamilton). Aquaculture Nutrition 8: 33-42.

Rakocy JE (2010) Aquaponics, integrating fish and plant culture. In: Timmons MB, Ebeling JM (ed) Recirculating Aquaculture. Cayuga Aqua Ventures. USA. pp: 807-864.

Reyes DPP, González SR, Romero CO, Ponce-Palafox JT, Peillón VO, Castillo-Vargasmachuca S, et al. (2011) Producción de la macrófita acuática Lemna perpusilla utilizando agua residual de una instalación porcina, con propósitos para producción de biomasa para acuacultura. Biociencias 1: 17-27.

Rodrigues RT, Chizzotti ML, Martins SR, da Silva IF, Queiroz MA, Silva TS, et al. (2016) Energy and protein requirement of non-descript breed hair lambs of different sex clases in the semiarid región of Brazil. Tropical Animal Health and Production 48: 87-94.

Romero C, Nicodemus N, García-Rebollar P, García-Ruiz AI, de Blas C (2009) Dietary level of fibre and age at weaning affect the proliferation of Clostridium perfringens in the caecum, the incidence of epizootic rabbit enteropathy and the performance of fattening rabbits. Animal Feed Science and Technology 153: 131-140.

Rossow HA, Aly SS (2013) Variation in nutrients formulated and nutrients supplied on 5 California dairies. Journal of Dairy Science 96: 7371-7381.

Salas-Pérez L, Preciado-Rangel P, Esparza-Rivera JR, Álvarez-Reyna VP, Palomo-Gil A, Rodríguez-Dimas N, Márquez-Hernández C (2010) Rendimiento y calidad de forraje hidropónico producido bajo fertilización orgánica. Terra Latinoamericana 28: 355-360.

San Martín C, Boetscher C (2003) Importancia ecológica de la heterofilia en Limnobium laevigatum. Boletín de la Sociedad Argentina de Botánica (Supl): 131-132.

Sinha RK (2004) Modern Plant Physiology. Alpha Science International, India. Pp: 620.

Sorensen P, Norgaard JV (2016) Starfish (Asterias rubens) as feed ingredients for piglets. Animal Feed Science and Tecnology 211: 181-188.

Souza AP, Medeiros AN, Carvalho FFR, Costa R, Ribeiro LPS, Bezerra AB, et al. (2014) Energy requirements for maintenance and growth of Canindé goat kids. Small Ruminant Research 121: 255-261.

Thiex NJ, Anderson S, Gildemeister B (2003) Crude fat, hexanes extraction, in feed, cerealgrai, and forage (Randall/Soxtec/Submersion Method): Collaborative Study. Journal of AOAC International 86: 899908.

Varela de AAM, Lopes DC, Motta FW, Santiago RH, De Quiroz AC, Sales PE, et al. (2003) Performance and carcass characteristics of rabbits fed diets with differents starch levels and fiber sources. Revista Brasileira de Zootecnia 32: 1311-1320. 
Watson SW (1971) Taxonomic considerations of the family Nitrobacteraceae Buchanan. International Journal of Systematic and Evolutionary Microbiology 21: 254-270.

Wersal RM, Madsen JD (2011) Influences of water column nutrient loading on growth characteristics of the invasive aquatic macrophyte Myriophyllum aquaticum (Vell.) Verdc. Hydrobiologia 665: 93-105.

Wilkonson SJ, Selle PH, Bedfor MR, Cowieson AJ (2014) Separate feeding of calcium improves performance and ileal nutrient digestibility in broiler chicks. Animal Production Science 54: 172-178. 
